Georgia State University

ScholarWorks @ Georgia State University

$1-2-2013$

\title{
Sidney and Beatrice Webb's Institutional Theory of Labor Markets and Wage Determination
}

Bruce E. Kaufman

Georgia State University, bkaufman@gsu.edu

Follow this and additional works at: https://scholarworks.gsu.edu/uwrg_workingpapers

\section{Recommended Citation}

Kaufman, Bruce E., "Sidney and Beatrice Webb's Institutional Theory of Labor Markets and Wage Determination" (2013). UWRG Working Papers. 67.

https://scholarworks.gsu.edu/uwrg_workingpapers/67

This Article is brought to you for free and open access by the Usery Workplace Research Group at ScholarWorks @ Georgia State University. It has been accepted for inclusion in UWRG Working Papers by an authorized administrator of ScholarWorks @ Georgia State University. For more information, please contact scholarworks@gsu.edu. 
Working Paper 2013-1-2

January 2013

\section{Sidney and Beatrice Webb's Institutional Theory of Labor Markets and Wage Determination}

Bruce E. Kaufman

Georgia State University

\section{ANDREW Young SchoOL}




\title{
Sidney and Beatrice Webb's Institutional Theory of
}

\author{
Labor Markets and Wage Determination*
}

\author{
Bruce E. Kaufman**
}

(January 28, 2013)

*Forthcoming, Industrial Relations.

Bruce E. Kaufman (bkaufman@gsu.edu) is a Professor in the Department of Economics, Andrew Young School of Policy Studies, and an associate of the W.J. Usery Center for the Workplace at Georgia State University. He is also affiliated with the Centre for Work, Organization and Wellbeing and the Department of Employment Relations and Human Resources at Griffith University in Brisbane, Australia, and the Work and Employment Research Unit at Business School of the University of Hertfordshire in Hatfield, United Kingdom. 
Sidney and Beatrice Webb's Institutional Theory of Labor Markets and Wage Determination

"The labor view [was] first and most effectively developed by the Webbs, where they set out, in a literary way, the whole notion of inequality of bargaining power, and there wasn't a man in the United States - or in the world - who taught this stuff, or any writers of textbooks in succeeding generations, who didn't say this." (Wolman, 1961: 55)

The institutional and industrial relations schools were the dominant groups in labor economics into the 1960s (Boyer and Smith 2001; Kaufman 2006) and among early writers the British husband-wife team of Sidney and Beatrice Webb played a particularly important role - per the Wolman epigraph (also see Douglas 1948). Among the dozens of books and articles they wrote over a six decade career, the 900+ page volume Industrial Democracy (1897) stands out as their magnum opus. The book is an exemplar of the early institutional approach in political economy (Rutherford 2011) - exhaustive on-the-ground investigation, an inductive/empiricist approach to theory development, a corpus of theory integrating in a literary way ideas and insights from diverse writers and disciplines (Smith, Marx, Marshall; economics, sociology, history), and a progressive policy program emphasizing social control and reengineering of institutions to produce more efficient and equitable outcomes.

The Webbs are the subject of a modest literature of biography and political thought (Cole 1971; Nolan 1988; Harrison 2000; Eriguchi 2009) centered on their role in founding and developing the Fabian Society and its creed of evolutionary state socialism. Next is a smaller body of work that examines the Webbs' place in the late 19th century dissident movement associated with the British version of the Methodenstreit (war over method) and corollary efforts to develop a historical-social-institutional type of economics (Koot 1987; Rutherford 2007). Part of this story is the Webbs' decision to found the London School of Economics (LSE, 
1895) as a way to circumvent the orthodox hold on British economics exercised by Marshall and associates at Cambridge and Oxford (Kadish 1982; Perlman and McCann 1998).

Next in the list are the Webbs' historical and empirical studies on labor problems, institutions, and policy. They were late 19th century pioneers of the social science research program on the conditions of labor (McNulty 1980; Harrison 2000; Kaufman 2012a); are widely regarded as co-founders of the field of industrial relations for their seminal trade union studies (Hyman 1989; Frege 2008); and provided often-cited analyses and rationales for collective bargaining, minimum wages, and the modern social welfare state (Bevir 2002; Farnham 2008; Kaufman 2005, 2009). Of these subjects, the Webbs' writings on trade unions today still get occasional if somewhat ritualistic citation.

Least known is the Webbs' attempted reformulation of labor market theory. Critics claim the Webbs and other labor institutionalists were anti-theory and contributed little beyond a mass of facts and description (Stigler 1959; Boyer and Smith 2001). However, one notes in the preface to industrial Democracy (1897) the Webbs tell readers, "we have ventured into the domain of theory ..... [and] have laid before the student a new analysis of the working of competition in the industrial field" (p. viii, emphasis added). Although lost today, this "new analysis" was widely known and quite influential in the pre-World War II years (e.g., Millis and Montgomery 1945) and provided part of the economic and social rationale for the New Deal labor program in the USA (Kaufman 2012b).

This article describes and recasts into modern terms the labor market theory of the Webbs. It is organized into ten linked topic areas. A history of thought purpose is served; more important, however, is utilizing the Webbs' ideas to further develop and strengthen the institutional economic theory base for labor economics and industrial relations. Prior studies 
that touch on aspects of this article include Davanati and Pacella (2004), Dickman (1987), Fried

(1998), Rutherford (2007), and Kaufman (1998, 2005, 2009).

The Webbs: Background

Sidney Webb and Beatrice Potter, married in 1892, were one of the most productive and influential husband-wife research teams in the history of the social sciences (Harrison 2000).

They spent the 1880 s learning economics, albeit outside of universities since Cambridge and Oxford were closed to both -- he because of insufficient socio-economic position and she because of gender.1 As detractors see it (e.g., Stigler 1959), the Webbs were economic amateurs who didn't learn their theory very well; admirers, on the other hand, see major contributions marginalized by mainstream commitment to free market theory and politics (Cole 1971; Harrison 2000). They were well read in the British classical economics of Smith, Ricardo, and Mill; absorbed Marx in study group; were tutored in Jevon's new marginalist economics by Edgeworth and Wicksteed, personally knew Alfred and Mary Paley Marshall, and thoroughly studied his Principles of Economics (1890). Sidney Webb published articles on economic theory in Quarterly Journal of Economics, Economic Journal, and Journal of Political Economy.

Although the Webbs chafed at Marshall's political conservatism, they nonetheless acknowledged him as their leader in economics (Harrison 2000: 283), concluded the JevonsMarshall marginalist-based approach to theory had the most solid micro-foundation, and had substantial hopes that Marshall would incorporate significant historical, institutional and

\footnotetext{
1 Strong social norms blocked women's education and career advancement in late 19 century Britain. Illustratively, Alfred Marshall remarked to Beatrice Webb that, "If you compete with us we shan't marry you" and therefore, "the woman must not develop her faculties in a way unpleasant to the man: that strength, courage, independence were not attractive in women; that rivalry in men's pursuits was positively unpleasant [and].... masculine ability in women must be firmly trampled on and boycotted" (B. Webb 1926: 300). Marshall strenuously sought to keep women out of Cambridge University, even though his wife was a published economist.
} 
evolutionary components in the theory text he was laboriously working on through much of the 1880s. When eventually published as Principles of Economics in 1890, the book in the prose part did give sympathetic discussion to these elements, and also specific ideas such as inequality of bargaining power in labor markets - just as Adam Smith had in the Wealth of Nations (1776/1937). Marshall considerably disappointed the Webbs, however, when in the analytical development he reverted to a model of pure competition in wage determination.

On the other side of the political/economic spectrum was Karl Marx. Sidney Webb discussed economics with Marx's partner Friedrich Engels and concluded after reading Marx's masterwork Capital (Vol. 1: 1867, Vols. 2 \& 3: 1885) that he got closer to the truth about laissezfaire capitalism - with its widespread poverty, deplorable factory conditions, and periodic bouts of mass unemployment -- than did Marshall. Webb also concluded, however, that Marx's labor theory of value was ill-conceived as was his doctrine of revolutionary class struggle.2

Accordingly, the Webbs' set out to develop a middle way in economic theory with elements of both marginalism and Marxism, contributions from Mill, Smith and other British classical economists, and attention to new developments in German social-historical economics (Rueschemeyer and Van Rossem 1996). They describe their approach as political economy embedded in the discipline of sociology. Schumpeter (1954) labels their work "economic sociology"; Boulding (1957) calls it part of "London School Institutionalism"; and Koot (1987) includes it as part of "English historical economics" and Fabian "social democratic economics."

In America, much the same middle way tradition emerged in the 1880 s, albeit with less influence from the British classical writers and more from German economists such as Roscher

\footnotetext{
${ }^{2}$ In return, Lenin (quoted in Clarkson 1953: 462) called the Webbs "bourgeoisie humbugs" and Engels referred to the Fabians as "a well-meaning gang of educated bourgeois who have refuted Marx with the rotten economics-made simple of Jevons, which is so simple that one can make anything out of it" (quoted in Rueschemeyer and Van Rossem 1996: 125).
} 
and Knies (Jacoby 1990; Kaufman 2004, 2010; Rader 1966). Late 19th century American pioneers of this tradition were Ely, Adams, and Patten; in the early 20th century this stream of thought evolved into institutional economics under Veblen, Hamilton, Commons and others (Rutherford 2011). The labor branch of institutionalism was heavily associated with Commons and the Wisconsin School and developed into the field of industrial relations (Kaufman 2010). Commons (1934a: 71) acknowledges in his autobiography that a number of ideas found in his institutional economic theory and writings on labor/industrial relations come from the Webbs.

Ironically, before World War II it was the Webbs (sociologists), not Commons (labor economist), who had the larger theoretical influence on the field of labor economics (Douglas 1948). Conversely, in the same period it was Commons, not the Webbs, who pioneered the development and conceptualization of industrial relations as a field (Kaufman 2004). Their respective roles are often portrayed in the literature in reverse order.

\section{Revised Labor Market Theory: Introduction}

The core theoretical chapter in Industrial Democracy (1897) is "The Higgling of the Market," described by Chicago labor economist Paul Douglas (1921: 98) as "incomparable." Following Marshall, the Webbs state "we must assume a market in a state of perfect equilibrium" (1897: 655).3 Their departure point is the argument that this model, without further development, is incomplete at key points and therefore a misleading tool for prediction and welfare analysis. The reason given (same page) is that it "ignore[s] the actual structure of the industrial world" and confines analysis "to the abstract figures of 'the capitalist' and 'the laborer'" (emphasis added). Friedman (1953) later characterized this kind of criticism as misguided demand for

\footnotetext{
${ }^{3}$ Citations for the Webbs are simplified to only the year for their joint publications.
} 
descriptive realism, a charge widely repeated over the years by neoclassical detractors of the institutional approach (e.g., Boyer and Smith 2001).

Marshall did not draw a demand/supply (DS) diagram for labor markets in the Principles but, for analytical purposes, he maintained that wage rates, like other prices, can be modeled as if they are the outcome of a competitive demand-supply bidding process. Hence, Marshall asserted that the difference between commodity markets and labor markets is "not fundamental from the point of view of theory" (8th ed., p. 336). The Webbs (1897) disagreed. They claim, "the assumption of a mutual exchange of services among freely competing individual bargainers, is, from a practical point of view, entirely obsolete. We have, in fact, to work out a new scientific analysis" (p. 688, emphasis added). It is described below.

Rent Theory: The Foundation

The Webbs do not deny a role for demand and supply in labor markets; rather, they reject the Marshallian model of pure competition where demand and supply operate in isolation of social and institutional context. One problem is that without these factors Marshall's model contains an important element of indeterminacy since DS curves by themselves can be located at any point in price/quantity space, thus leaving the identification of the actual wage rate and wage structure "hanging in the air" - per a similar criticism made by Coase (1992). The standard practice is to draw the curves in the middle of the DS diagram but this begs the question and, also, perhaps misleadingly indicates a balanced wage outcome. A second problem is that Marshall's model tilts evaluation of labor policy toward laissez-faire and the status quo. Competitive outcomes are presumptively efficient and therefore desirable; market failures become exceptions to the competitive rule; social considerations of fairness and inequality are omitted; trade unions and labor laws acquire a "guilty until proven innocent" aura; and 
pathologies such as exploitation, persistent unemployment, and widespread poverty are either rendered logically impossible or attributed to human failings and institutional obstructions.

In History of Trade Unionism, the Webbs speak of Marx's "erroneous theory that labor is by itself the creator of value" and then say that their alternative theory is based on "that impregnable and more difficult law of economic rent" (1894: 146-47). They and fellow Fabians (e.g., Hobson 1891) were attracted to the law of economic rent since it had an impeccable British pedigree (Ricardo 1817), could be developed in the new marginalist framework popularized by Jevons and Marshall, had acquired worldwide attention through the proselytizing efforts of "single land tax" Henry George, can be applied to labor markets in a way that brings in the social/institutional structure surrounding DS, and opens up greater analytic and ethical space in economic theory for a positive role for trade unions, social reform, and redistribution of wealth and power. Because their theory of wage determination is grounded on Ricardo's rent theory, it has become known in the small follow-up literature simply as "rent theory" (Ricci 1969; Bevir 1989; Lobdell 1995); however, to keep the Webbs' version distinct from other theories of rent I label it Webbian rent theory (WRT).

WRT was influential in Britain, particularly in Labor Party circles, up to the World War II period and then faded. In America, it never got much of a foothold (Fried 1998), although Commons in his early marginalist phase featured the rent concept in his theory of distribution (Commons 1893). The American and British literatures of post-WWII labor economics and industrial relations do not mention WRT.

Economic rent is a payment to a factor of production above its minimum supply price. A reason the Webbs gravitated to the idea is that it provides a non-Marxian version of surplus value both at an individual and social level of analysis. In the neoclassical competitive model, 
wages in the short-run may contain significant rent elements but in the long-run competitive market forces reduce these premiums to zero. Implications are that factor prices are minimum socially necessary payments to compensate capital, labor and land for their opportunity costs and participation in production; no factor suffers exploitation (i.e., payment below value of productive contribution); and demand and supply distribute income shares to the factor owners that add-up to the value of income created (the neoclassical product exhaustion theorem).

Different assumptions yield different conclusions. Two that the Webbs change are, respectively, the competitive model's homogeneous labor assumption and the definition of minimum socially necessary labor cost. Both follow from Ricardo and Smith and are, in the minds of the Webbs, strategic additions of realism.

Regarding factor homogeneity, Ricardo (1817) argued that land varies in fertility and economic rationality leads farmers to begin production with the most fertile acres. For a given market price of agricultural goods, farmers extend the extensive margin of cultivation until the incremental return from the last and least fertile acre just equals the incremental production cost. Infra-marginal units of land, therefore, yield an economic rent (as defined above) but the last unit yields zero-rent. The Webbs reasoned that if Ricardo's differential rent idea applies to land then it should also apply to labor (1897: 730; 1902: Ch. 9). Land differs by fertility and workers differ in productivity due to attributes both innate and acquired. In the former category are physical strength, intelligence, and drive; in the latter are education, training and social capital. Thus, factory owners, like farmers, hire the most productive people first and work down the queue until the return from the last worker just equals the market wage. The least productive worker defines the "margin of employment" and yields zero-rent; infra-marginal 
labor yields positive rent that competition even in the long- run does not eliminate - like the long-run rent accruing to a rich vein of ore or proprietary piece of capital equipment.4

The idea that the marginal employed worker yields zero rent is common between Marshall and the Webbs. The question, however, is: where will the zero-rent wage be in longrun equilibrium? The Webbs (1897: 643-46) note that Marshall vacillates on the matter; following Ricardo and Smith, however, they give a concrete answer. In neoclassical theory, the supply price that determines the amount of labor offered in the market comes from the positively sloped market supply curve and is given by the reservation wage of the marginal worker, as derived from the labor-leisure choice model. However, the Webbs argue that absent a welfare state or substantial non-labor family income the choice for ordinary workers is less labor vs. leisure and more labor vs. homelessness and starvation (1897: 677). Thus, the reservation wage may incorporate the marginal opportunity cost of leisure for well-paid workers; for workers at the bottom of the labor market, however, their reservation wage is grounded on family sustainability costs. The classical economists called this income level the subsistence wage, denoted here as Ws, but with recognition that "subsistence" has both a physiological and social/cultural element and is therefore higher in more advanced societies.5 Smith (1776/1937: Book I Ch. 7) calls Ws the "natural rate" of wages; the Webbs called it the "living wage."

The rent idea gives the Webbs the means to ground the wage structure in price-quantity space. Their tact is to identify the wage of the lowest category of unskilled manual labor, use it to peg the bottom of the economy's wage structure, and then locate the wage rates of higher-

4 This idea is the antecedent to the popular resource based view (RBV) of the firm in modern-day strategic human resource management (Allen and Wright 2007). 5

The sustainable wage in the USA is approximated (although probably understated) by the poverty line. In 2011 it was $\$ 11,139$ for an individual person. This income level, for a 2000 hour work year, yields $\mathrm{W} s=$ $\$ 5.70$ (relative to a legal federal minimum wage of $\$ 7.25$ ). With three extra people in the family, the poverty threshold rises to $\$ 22,314$, making $W_{s}=\$ 11.16$ for a one-person full-time breadwinner. The poverty rate was 15.1 percent. The history of the living wage concept is discussed in Stabile (2008). 
paid workers on top of Ws as they vary by productivity, market power, and social capital. To do so, the Webbs follow the classical economists and posit that the long-run tendency in the labor market is for competition to drive the unskilled wage down to Smith's natural rate (1902: xxiii). They cite several reasons. For example, in the short-to-medium run a wage level above Ws encourages immigration from lower income countries and this labor inflow continues to shift the labor supply curve rightward until the wage falls to Ws. Per Marx, the Webbs also contend the normal position in a capitalist economy is excess labor supply and, therefore, the reserve army of unemployed causes a bidding-down of wage rates to (or below) the subsistence rate. And, per well established classical economic doctrine, they also reasoned that when $\mathrm{W}>\mathrm{W}$ s the population grows from natural increase (births $>$ deaths) and brings with it expansion of the future labor force --a not-too-distant effect with child labor -- until the wage falls back to Ws.

The Webbs claim, therefore, that for theoretical purposes the common labor rate of wages is established by economic forces at Ws with short-run movements above and below it coincident with macroeconomic cycles; over time Ws slowly moves up with social advance. The common labor rate also defines the zero-rent marginal unit in the labor market. The importance of these conclusions for the Webbs' theory of labor markets is indicated by Sidney Webb who says that upon it "all economic deductions depend" (1902: 213). The specific reason he gives is that, "To this normal level the wages of all unskilled workers tend to come; and from this economic datum-line the extra produce known variously as rent, interest, wages of superintendence, or generally as profits or surplus value, must be computed" (ibid., 213-214).

Accordingly, the Webbs build on top of this foundation the wage structure for higher paid workers. It is an amalgam of compensating and non-compensating differentials (1902: xiii, 209-217) as similarly theorized by Smith (1776/1937: Book I, Chapter 10). The former reflect 
factors such as costs of human capital investment in education and training and differences in job amenities and worker attributes; the latter reflect the influence of institutional, political and social factors. These non-compensating determinants of wages operate both "before the market" and "within the market" (Phelps-Brown 1977). Many take the form of an entry barrier or competitive shield, labeled "dykes and bulwarks" by the Webbs (1897: 662).

WRT provides a different view of labor markets at key places. For example, wage rents and non-compensating wage differentials are neither spotty nor temporary but widespread and persistent. This situation arises partly from the heterogeneous nature of labor which, in the Webbs' terminology, creates "rents of "ability" and "rents of opportunity" (1897: 804). The largest source of rents, however, is human-made through political and social institutions which determine endowments, opportunity sets, and rules of the game before the labor market and the extent and structure of competition people face within the labor market. Here economics merges with law, political science, and sociology since political power, social position, and the legal regime are primary instruments people use to advance their interests in the contest for rents (Samuels and Schmid 1981; Domhoff 1990; Sørenson 1994). Illustratively, the Webbs speak of a "tacit conspiracy among the more favored classes to maintain or improve their own positions of advantage at the cost of the community at large" (1897: 598). Institutions, therefore, affect the wage structure by differentially positioning DS curves and creating non-DS outcomes.

Labor rents are not randomly scattered across the workforce but tend to vary directly with earnings, social/occupational position, and class. Common laborers, for example, are fully exposed to competition and must sell their labor for whatever it will bring every day, given lack of fall-back financial resources, protective entry barriers, or specialized human/social capital. Their choice in the labor market is one unattractive low paying job or another. Executives and 
people the Webbs call "brain workers," on the other hand, have better paid and more attractive employment options because their scarce skills and knowledge, advantageous social class, larger wealth resources, and superior access to power put them into more specialized and protected niches in labor markets where rents are more abundant and easily captured. Modern-day executives, for example, have stock-option plans and golden parachutes, professors have tenure rules giving career-long job security, and sports stars have unique physical talents.

In the Webbs' theory, therefore, the labor market is an institutional pyramid (1897: 671). It has a broad base among "no-rent" workers in common manual, unskilled and service jobs. This stratum of the labor market is reasonably approximated by the model of pure competition since mobility is fluid and wages largely vary with the balance between demand and supply. The distribution of jobs and earnings above the base may have a bulge in the lower-middle stratum or, alternatively, uniformly slope from broad to narrow, depending on things such as the underlying industrial job skills distribution, extent of unionization and legislated social protection, and education level of the workforce (1902: 209). Whatever the exact shape, earnings in ascending strata contain proportionately more rent elements, jobs are more protected by institutional rules and barriers, and mobility is less fluid and job tenure longer (1897: 662, 677). The reality of large-sized rents is that most people in the upper stratum are paid considerably more than their minimum supply price for that line of work - exactly as predicted by modern tournament wage models (Neilson 2007). Similarly, empirical studies (e.g., White 2010) find that the new jobs of displaced workers on average pay significantly less.

Rents in Webbian theory are equivalent to surplus value in Marx's economics in the sense of representing a factor payment above the value of productive contribution (1902: 216). The two conceptions are distinct yet overlap. Like Marx (and Smith before him), the Webbs 
believe every economy above the subsistence level yields an economic surplus (1902: 223). The economic surplus is, heuristically speaking, society's discretionary income in that it represents the difference between GDP and the factor payments necessary to maintain and reproduce the stock of capital, labor and land (Davis 1992). The economic surplus is zero in neoclassical competitive equilibrium because all factor payments are social costs just necessary to induce the marginal units of the factors to offer their services. Classical-based economic theory, however, arrives at a different answer because rents are intrinsic and inevitable in every economic system (1897: 594). The aggregate supply curve of land, for example, is vertical and hence all payments - at least above those for improvements - take the form of rent (surplus). Using a labor theory of value, Marx (1867) argued that the return to capital owners is also a pure rent and, hence, on ethical grounds profit is labor exploitation. As earlier quoted, the Webbs rejected Marx's value theory and hence could not follow him and categorically lump all profit and interest as unearned income. However, they also rejected the neoclassical view that in a competitive system equilibrium profits and interest are entirely productivity-based rewards. Like labor earnings (discussed above), returns to capitalists have a productivity component but are also inflated by often large rent components arising from monopoly-like structural conditions in product markets, laws and regulations that shelter firms from full domestic and global competition, and symbiotic/collusive links between bankers and capitalists (1902: xvii-xxii).

In WRT, therefore, both the economy in general and labor market in particular generate substantial surplus at a point in time and growing surplus over time (as factor demand curves shift along forward to-vertical sloped supply curves). Since higher income groups - relative to common labor - receive a greater proportion of returns from factors having more inelastic supply curves, an implication is that over time capitalist economies have a built-in tendency toward greater income inequality. They also have a tendency to exploit labor at the bottom end 
of the labor market pyramid. The Webbs do not explicitly define labor exploitation; however, from their point of view it is real enough when millions of people work the entire year to help produce the nation's surplus and yet they get none of it - being paid just enough (Ws) to maintain themselves in order to show up for work the following year (1897: 751). For this reason they claim capitalism, and the upper classes who consume most of the surplus it produces, are properly considered as (in part) parasitic (ibid.).

Filling-in Rent Theory: Bargaining Power

Rent theory provides a first approximation answer to identifying the location of labor demand and supply curves, the structure of wages, and labor's share of national income. The Webbs then add several more aspects of structure to fill it out, in part to further locate demand and supply curves and in part to divide surplus where market forces are restricted by natural and man-made entry barriers and the resulting price indeterminacy due to frictions and small numbers. The first addition is bargaining power.

Adam Smith (17776/1937, Book I, Ch. 8) portrayed wage determination as a contracting process with the wage set by the relative bargaining power of the employer and employee. He observes, "It is not, however, difficult to foresee which of the two parties must, upon all ordinary occasions, have the advantage in the dispute" (p. 66). His answer is the employer. Smith's idea that individual workers bargain at a disadvantage with employers was widely accepted in orthodox circles in the 19th century, including Mill, Jevons and Marshall. The Webbs' contribution is to give more prominence and theoretical grounding to the idea.

Bargaining power in wage determination, they assert, is a function of alternatives and hold-out ability (1897: 655-56). The general case is that workers are in the weaker position, although the degree of weakness varies inversely with skills, education, income, social 
advantage, and macroeconomic prosperity. In general, firms enjoy the bargaining advantage because they have deeper pockets to hold-out, can inventory their product better than workers can inventory their labor service, have more alternative job applicants than workers have job possibilities, and are more knowledgeable about market conditions and the art of bargaining for the best terms. The workers' structural disadvantage is then compounded by the presence in most years of more jobseekers than jobs. In a DS diagram, labor's weak bargaining position means workers have a lower reservation wage and, accordingly, the labor supply curve is shifted to the right and the equilibrium wage is lower. Correlatively, this also means the dollar value of the entire structure of compensating wage differentials falls to a lower level.

The Webbs augment the inequality of bargaining power idea with the concept of "chain of bargains" (1897: 663-74). They claim that bargaining power diminishes and competitive pressure intensifies as one goes down the vertical stages of production from consumers at the top of the pyramid to production workers at the bottom. In their words, "the consumer [is] the ultimate source of that persistent pressure on sellers, which, transmitted through the long chain of bargaining, finally crushes the isolated workman at the base of the pyramid" (1897: 671).

Consumers are at the top of the bargaining pyramid because they typically have the greatest number of easily accessed alternative sources, smallest worry of losing-out from additional search, and least financial pressure to quickly purchase. Consumers, therefore, shop around and exert pressure on retailers to shave prices and costs to win their business. The pressure for lower prices and costs then ripples down the stages of production from retailers to wholesalers to manufacturers. The manufacturers look for lower prices and costs from their input suppliers. Of all suppliers, labor typically accounts for the largest proportion of variable 
cost and has the most flexible contracts; hence, manufacturers and raw material producers concentrate their pressure for lower cost on labor.

All suppliers in the chain of bargains feel competitive pressure to lower prices and, without a market-wide barrier somewhere in the pyramid, it cascades downward until coming against the bottom of the pyramid. Accordingly, "If the wages of common labor are left to 'supply and demand,' .... we shall find wages everywhere forced down, for the ordinary, common unskilled worker, to their 'natural level' - that is, to the barest subsistence of the human animal from day to day" (1902: xxiii). Lacking the number and strength of natural and human-made dykes and bulwarks available to sellers at higher levels of the pyramid, the lower class of workers instinctively resort to one of the few competitive shields available - restrictive social norms against wage-cutting, working too fast, and hiring women and immigrants (1897: 694-700). Violation of these norms evokes various sanctions, including strikes and mob violence, but they cannot permanently hold the line against the competitive pressure of the market.

Labor Market Duality and Dynamics: Low Road and High Road

Models of dual, segmented, and balkanized labor markets are common in the institutionalist literature (Kerr 1977; Gordon, Edwards, and Reich 1982). The writings of the Webbs contain this idea but embedded in a dynamic, evolutionary process. They recognize that labor markets and employment relationships fall along a continuum in terms of "good" and "bad" features, such as wages, job security, training, and treatment. For purposes of generalization, however, the Webbs distinguish two polar opposite situations. The labels they use vary, such as "low channel" vs. "high channel" and "sweated trade" vs. "labor aristocracy," but the ones used most frequently and which also capture the dynamic element are "progress" vs. "degeneration" (1897: 703-04; 753). Apropos labels today are "low road" vs. "high road" employment systems. 
This duality comes from a combination of technological, institutional and human features. A consequence of assuming heterogeneity in factor inputs and production sets is that firms have different cost curves and, given a uniform market price for the good, different levels of profit. As a useful generalization, some firms are very technologically advanced, have efficient managements, and operate at a larger minimum efficient scale. These firms earn above normal profits and, for human motivational reasons, share some of their rents with workers. On the other end of the same product market are undercapitalized, small-scale, and poorly managed firms with higher cost curves that put them in a constant struggle to stay in business. Here, instead of sharing rents, these firms stay in business by taking it out of workers in the form of wages and conditions below the competitive social cost level. The Webbs characterize the worst of these firms as sweatshops and note, "the bottom of the industrial army.... suffers not from great capitalists but from small masters" (1902: xvii).

Institutional factors also encourage a dual structure. The larger and better managed firms often develop internal labor markets (Doeringer and Piore 1971). This term was not invented when the Webbs wrote but they observed that certain large employers in the late 19th century were already using various devices to create a long-term employment relationship on the belief it increases productivity and profit (1897: 661-62). Smaller-scale and less efficiently managed firms, on the other hand, gain cost advantage by relying on the external labor market with low wages, high turnover, and bare bones training and conditions. Other institutional factors creating a dual structure are sectional collective bargaining, gendered social norms, and labor laws specific to occupations and industries.

Dualism is also promoted by human factors. For example, following Smith (Reisman 1976) the Webbs assert that worker productivity is a positive function of the wage (1897: 690; S. 
Webb 1912). In the Webbs' era this idea was called "economy of high wages," today it is called efficiency wage theory. Firms using specific skills and internal labor markets find sharing rents adds to profits by creating higher productivity, unity of interest, and lower turnover; conversely, firms using general skills and external markets do not since workers are a fungible commodity and work effort and compliance are gained through control and coercion.

In dynamic terms, the Webbs assert labor markets can follow one of two alternative equilibrium paths. One is the low channel and the other the high channel. Competition is blind and a-moral and therefore follows the path of least resistance. Without regulation and other dykes and bulwarks at the bottom of the pyramid, the path of least resistance is cost-cutting, commodification of labor, deskilling, and work intensification - all which leads to a cumulative deterioration in labor markets and a social lose-lose. If competitive advantage is instead gained through higher quality products, superior technology, and higher workforce skills, the labor market follows a high road/high wage path to a social win-win.

The low road vs. high road dynamic is reinforced because human character and capability are a positive function of the quality of work life (1897: 583; S. Webb 1912). The productivity of inanimate capital and land are largely unaffected by work environment, managerial treatment, and hours of operation; these factors greatly affect, however, the performance of human labor. Also affected are workers' physical, mental and emotional capabilities and traits. Labor markets, for example, can produce a demoralized, degraded, and angry workforce or a cooperative, energized and virtuous workforce.

Labor Markets: Freedom and Fairness

Next introduced are two other distinctly human features that affect wage determination and impose further structure on labor markets. They are freedom and fairness. 
Neoclassical economics celebrates competitive labor markets because they give workers the widest scope for exercise of choice and utility-producing exchange; for similar reasons they oppose government and union regulation as infringements on individual liberty and freedom of contract. Economists also justify excluding fairness from labor market theory in order to maintain its scientific objectivity. The reality, the Webbs argue, is that absent regulation both external and internal labor markets can be home to substantial coercion and injustice which harm productive efficiency and violate fundamental ethical values. With regard to the ethical dimension, the Webbs observe that in competitive markets the economists' idea of freedom "may mean nothing more than.... by dint of continual toil [workers] continue to exist on the very brink of starvation" (1923: 46) while the economists' blind eye to employer autocracy in firm governance means they see "no more inconsistency between democracy and unrestrained capitalist enterprise, than Washington or Jefferson did between democracy and slave-owning" (1897: 841). Thus, what economists call scientific objectivity is a façade which hides their value choice to prioritize more consumption goods and the welfare of the affluent (those with most dollar votes) over better working conditions/treatment and the interests of common labor.

Quite apart from normative considerations, the Webbs argue that omitting fairness from labor theory makes it a poor scientific tool and harmful guide to practice. For example, they observe that employees restrict cooperation and effort if they feel unjustly or autocratically treated (1897: 661-62) - a conclusion confirmed and rediscovered in labor market experiments and behavioral theories of wage determination (Fehr, Goette, and Zenhder 2009; Akerloff and Yellen 1990). The fairness $\rightarrow$ productivity link is fundamental to institutional economics and industrial relations since it explains the formation of internal labor markets and high performance work systems, the efficiency advantage of stable wages and secure jobs, and the 
corrosive effect on workplace trust and cooperation from treating workers as a fungible "buy low/sell high" commodity (Fox 1974; Hecksher and Adler 2006; Kaufman 2010).

At a societal level, the polity in each nation has a concept of what is fair and unfair in labor markets and employment relations. Although this notion is contested, subjective, and approximate, the Webbs assert there are reasonable bounds on wages and conditions that public opinion accepts as legitimate and defensible (1902: 115-119). If these bounds are violated, social and political pressures build to remove the injustice by changing endowments and rules of the game. The manner, timeliness, and effectiveness of this pressure for greater social justice depend on each nation's political traditions and social choice mechanisms, such as monarchy vs. democracy and norms of individualism vs. collectivism. Nonetheless, widely-felt social injustice in labor markets predictably leads to individual and collective responses, such as turnover, union formation, spontaneous strikes, voting out political incumbents, and mass marches (Kelly 1998). Thus, the political framework that structures demand and supply responds to these pressures and, in the words of the Webbs, if sufficiently elastic and prescient "result[s] in political and social stability......and erect[s] a bulwark against revolution" (1897: 630).

Social Cost

A lesson of economic theory is allocative efficiency requires that prices of goods and services equal social costs of production. If private cost is less than social cost, the result is market failure, negative externality, and inefficiency (Coase 1992).

The Webbs claim a defect of laissez-faire capitalism is that many firms avoid paying full social cost of labor (Kaufman 2009). Instead, as a form of negative externality they shift a portion of social labor cost to workers, families, communities, and society at large (Stabile 2008). The Webbs state on this matter (1897:751): 
"The continued efficiency of a nation's industry obviously depends on the continuance of its citizens in health and strength. For an industry to be economically self-supporting, it must, therefore, maintain its full establishment of workers, unimpaired in numbers and vigor, with a sufficient number of children to fill all vacancies caused by death or superannuation. If the employers.... hire them [workers] for wages actually insufficient to provide enough food, clothing and shelter, ....or if they can subject them to conditions so dangerous or insanitary as positively shorten their lives, that trade is clearly obtaining a supply of labor-force which it does not pay for.... [This is] a vicious form of parasitism."

Employers individually and as a group are able to shift social labor costs through a number of channels. In a private enterprise economy, for example, labor is a (mostly) variable cost and can be laid-off at will; hence, after lay-off the workers' subsistence costs continue but firms cease paying them and either some third party picks up the expense (workers from savings, communities from bread lines and homeless shelters, society from uncovered health care costs) or the workforce deteriorates. Adding an additional element of inhumanity and unfairness, even as the firms put their rented human capital (workers) out on the street they keep their owned physical capital (buildings and equipment) on site and maintained even if idle.

Also, in neoclassical competitive theory compensating wage differentials ensure socially efficient levels of safety, health and working conditions. However, as noted above, unequal bargaining power shifts the labor supply curve to the right, reduces the size of such differentials (perhaps to zero), and permits firms to pay workers less for these social costs. Also described earlier, the same result happens because many working conditions are indivisible and take on the nature of a public good. As a last example, the Webbs (1897: 750; S. Webb 1912) contend firms gain a bounty from women workers because they can pay a wage lower than Ws with the expectation the women's families subsidize the difference.

Unemployment

The most egregious source of unequal bargaining power comes from a market failure that is the Achilles Heel of capitalism. It is the presence in all but exceptionally prosperous years of a 
"residuum" of involuntarily unemployed workers - often numbering in the many millions. This

factor - akin to Marx's reserve army of the unemployed -- has already been noted but needs

brief elaboration, given its crucial role in the Webbs' schema.

The effect of the unemployed on wage determination is indicated in this passage:

"When the unemployed are crowding round the factory gates every morning, it is plain to each man that, unless he can induce the foremen to select him rather than another, his change of subsistence for weeks to come may be irretrievably lost. Under these circumstances bargaining.... becomes absolutely impossible. The foreman has only to pick his man, and tell him the terms. Once inside the gates, the lucky workman knows that if he grumbles at any of the surroundings, however, intolerable; if he demurs to any speeding-up, lengthening of the hours, or deductions; or if he hesitates to obey any order, however unreasonable, he condemns himself once more to the semi-starvation and misery of unemployment" (1897: 660).

In neoclassical theory, an excess supply of labor indicates the price of labor is too high and wages need to fall until a DS equilibrium is reached where number of offered jobs equals number of job seekers. The Webbs, however, reject this self-regulating theory of labor markets.

At a microeconomic level, the labor supply curve at the base of the jobs pyramid (absent a welfare state, etc.) is negatively sloped and probably more elastic than the labor demand curve. In the downward direction, the key determinant of labor supply is minimum individual and family income (Ws). This income level becomes, in effect, a target in the family labor supply function. Therefore, a reduction in the wage in this region elicits a proportionate increase in proffered hours worked on the part of both primary and secondary earners (the added worker effect), making the labor supply curve in this region negatively unit elastic (Dessing 2002). The labor demand curve, on the other hand, is probably inelastic, particularly in periods of declining economic activity. The outcome, therefore, is that a fall in the wage is destabilizing -- labor supply grows faster than demand - and unemployment increases rather than decreases. 
At a macroeconomic level, the Webbs (1923) claim -- in line with other institutionalists (Kaufman 2012b) -- "there is no such 'invisible hand,' as Adam Smith romantically suggested” (p. 142) because of various coordination failures. One such failure arises from the staggered time sequence of buying and selling. The neoclassical model assumes the demand and supply functions across product and input markets can be solved as a set of simultaneous equations from which are derived equilibrium prices, wages and interest rates. This theory is a misleading abstraction, however, since in a real time economy with vertical stages in the production pyramid buying inputs in factor markets necessarily precedes completion of the final product which necessarily precedes sale to the consumer. Accordingly, it is impossible to solve the DS equations across these disparate markets for a time consistent set of equilibrium prices, leading to systemic coordination failure. The result of unguided and unplanned market coordination, therefore, is an "industrial anarchy" and "chaos of individualism" (Webb and Webb 1923)

Keynes (1936) was later to argue that government stabilization of aggregate demand could partially correct this kind of macro market failure. A generation earlier, however, the Webbs did not see this possibility, leading them to turn to wage regulation and economic planning as the solution (Webb and Webb 1923). This blind spot in their analysis is particularly ironic since fellow Fabian John Hobson (1900) used rent theory to construct a model that links inequality of bargaining power to rising income inequality (earlier described), slowing growth in household income and consumer spending, and eventual over-production and slump. This scenario is stated in the preamble to the National Labor Relations Act (Kaufman 2012b).

Political Economy of Wage Determination

The institutional view, shared by the Webbs, is that all markets, DS curves, and prices are socially created by a government-enacted and enforced web of rules and resource endowments 
(Irvine 1947: Rutherford 2011; Kaufman 2012c). Without this institutional framework, fundamental aspects of the economy, such as property rights, rules of competition, and the law of the employment relationship, do not exist and markets cannot function. Accordingly, while it may appear on the surface that impersonal market forces of demand and supply determine the wage structure it is actually the product of the underlying human-made institutional framework that sets the positions of the DS curves. Once political and social institutions specify the endowments of the agents and the rules of the game, the logic of self-interest in a perfectly competitive market mechanistically work-out the equilibrium values. DS only "determine" wages, however, in the same formalistic sense that the logic of algebra determines $2+2=4$.

The wage structure, including the shape of the pyramid and the position of people and classes in it, is therefore institutional and social and, accordingly, ultimately shaped by those who control the sovereign power of the nation state (Webbs 1923; Commons 1934b). In reality, the real invisible hand belongs to the government which (metaphorically) sits above the neoclassical DS diagram and through the web of rules and endowments determines where the demand and supply curves locate and intersect, much as a puppeteer invisible to the audience manipulates a maze of threads to locate the puppet's hands and legs. On this matter the Webbs (1902) state, "it is universally admitted to be the primary duty of Government to prescribe the plane on which it will allow the 'struggle for existence' to be fought out.... The whole history of Government is, indeed, one long series of definitions and limitations of the conditions of the struggle, in order to raise the quality of the fittest who survive" (p. 116). In a similar vein, capitalist firms are a miniature form of autocratic government and the demand for regulation and trade unionism is "a demand for a 'constitution' in the industrial realm" (1897: 841). 
More specifically, it is a social decision, not a law of nature or operation of Smith's

invisible hand, that determines whether a nation's firms and labor markets follow the high road or low road path and whether its workers labor twelve hours a day for poverty wages and no benefits or eight hours a day for middle class wages and universal health care. The Webbs' institutional economics indicates, therefore, that within limits a society can have the labor market conditions it chooses since nothing is foreordained about the current set of DS curves.

The structure of political and social control at a point in time creates the institutional order that bestows high wages to some people and low wages to others; changes in this system over time, in turn, shift DS curves and resulting patterns of production and distribution. In the 1700s, the landed aristocracy controlled the Parliament and exercised the most influence on the monarchy, while commoners where disenfranchised by highly restrictive suffrage rules. Not unexpectedly, the web of rules was structured such that the aristocracy and (later) capitalists reaped large rents for land and industrial enterprises while common laborers were forced off the land and made to work in hot and noisy mills twelve and fifteen hours a day for little pay and no safety protection (the verb "made" used to connote the coercion present when the only alternatives are destitution, crime, or emigration).

The Webbs thought the greatest potential for reform came from the spread of political democracy (1897: 841-842). The rights of suffrage for men were gradually extended through the 1800 s and by the latter part of the century included most wage earners. Not coincidentally, the Webbs observed, the British Parliament and two major parties (Liberals, Conservatives) began courting labor voters and restructuring the rules of the game to give workers access to better parts of the labor market and more of the discretionary surplus. To accelerate this process, the Webbs and fellow Fabians helped organize the Labour Party before World War I to create 
additional political competition and realignment of the institutional infrastructure. Immediately after World War II, the Atlee Labor government created, in the image of the Webbs, a modern welfare state in Britain (public education, housing, health care, pensions, etc.), enacted steeply progressive property and income taxes to capture unearned rents, balanced bargaining power by encouraging extensive unionization, and (in the image of Keynes) pursued full employment demand management policies (Thompson 1996). A similar story applies to the USA respecting the endogenous link between extending suffrage and political participation rights to women and minorities and the subsequent improvement in their labor market positions.

A popular but narrow interpretation of the Webbs' book Industrial Democracy is that it deals with bringing democracy to industry through unions and collective bargaining. A broader interpretation, consistent with their claim the book is a work in political economy, is it highlights that labor market outcomes are fundamentally determined at a political level (also, Commons 1924). Therefore, the book's message is that the best strategy to promote balanced and socially just outcomes in labor markets, eliminate social subsidies to owners of capital and land and social exploitation of labor, and give workers voice and participation at the workplace, is to create a full and effective democracy in the polity since wage-earners votes will always outnumber the electoral (if not dollar) votes of people getting most of their income from land and capital. They predicted that extension of education (hence the founding of the LSE), universal suffrage rights, the growing dysfunctionalities of capitalism, and expert administration and planning by government managers would move voters to seek a peaceful transition to a new economic system of democratic socialism (Webb and Webb 1923). Here the Webbs substantially overestimated on all counts.

Social Welfare Objectives 
The topic of the section to follow is the Webbs' position on labor policy; considered here, therefore, is their social welfare objectives or, more formally, social welfare function. Only with such a function can policy alternatives be evaluated.

The Webbs follow orthodox theory and make efficiency the objective of policy; they revise it, however, by shifting from allocative efficiency to social efficiency. They also adopt Bentham's utilitarian "greatest happiness" principle (1902: 117-21).

The concept of "society" has no place in neoclassical theory because agents in a competitive economy are modeled as individualist seekers of self-interest connected to one another only by prices and impersonal markets; indeed, to assume otherwise is to introduce forms of market failure. Since utility is ordinal, the welfare of individuals also cannot be compared or aggregated; further, by the Pareto principle changes in endowments and rules of the game are ruled out if one or more persons are harmed and cannot potentially be made whole from the benefits of the gainers.

The concept of society, on the other hand, is central to the Webbs and all institutionalists (Rutherford 2011). Living in a society means individual agents are conscious of their relationship to other people, are influenced by other's actions and outcomes, and regard their welfare as connected to the larger whole. Further, society is an organic macrocosm of the human agents composing it, implying society has a self-concept, a separate existence above and beyond any member, remains healthy and growing only if constituent parts are healthy and reproducing, and can use its collective brain (perhaps organized as representative government) to choose the future through deliberation and selective adjustment of institutions. Social efficiency, therefore, seeks the institutional order that best promotes the "good life" as measured by various economic and social indicators. The Webbs evaluate alternative states of 
social efficiency, in turn, using the utilitarian "greatest happiness" principle. Thus, they seek policy that promotes the highest welfare for society as a collective group and eschew the "tyranny of the marginal unit" that comes with the neoclassical Pareto principle. For example, they prefer to have workplace safety standards that match the preferences of (say) the median worker rather than the marginal worker since the latter effectively sacrifices the interests of the group for the interests of the person with least desire to pay for safety or most financially pressed to take a job even with minimal-to-no safety (1897: 779).

Social efficiency, accordingly, requires a balancing of interests and equalizing of opportunities to maximize the productive ability and personality development of all parts of the social body. Therefore, all levels of governance in society, such as firms, families, unions, and polity, need to provide channels for voice and representation so decisions are made via a pluralistic stakeholder model using a generic form of collective consultation, negotiation, and bargaining with rules mandating due process and protection of minorities. (Nolan 1988; Harrison 2000; Commons 1934b).

Labor Policy

The Webbs believe unregulated labor markets are subject to a version of Gresham's Law (1902: xxvii) and society must block-off the low road in order to protect the entire wage structure and, in particular, the position of the unskilled at the bottom of the pyramid. Thus, they observe, "What is most urgently needed .... is an extension of the strong arm of the law on behalf of the oppressed workers in the sweated trades" (p. xvii). This takes the form of a "National Minimum" established by the "Device of the Common Rule."

The national minimum covers all workers through four main branches of legislative enactment: a minimum level of wages, maximum level of work hours, minimum level of health 
and safety conditions, and minimum level of education (1902: xxv). These national minimums are supplemented by social insurance programs that hold-up workers' reservation wages and cover social costs (1897: 701), along with other measures such as a progressive income tax system, counter-cyclical public works spending, and collective bargaining. Through these proposals, the Webbs seek to put a floor under wages and conditions at the base of the pyramid. In institutional economics, this floor establishes the plane of competition (Adams 1886). At a point in time the floor should be positioned no lower than Ws so wages provide sustainable income to workers and cover the full social cost of labor; over time the floor should be raised so bottom-end workers share in the fruits of economic growth.

Neoclassical theory leads to a skeptical-to-negative evaluation of the Webbs' proposal for a legislated (or bargained) floor in labor markets. If above the market wage, these minima lead to fewer jobs, more unemployment, higher prices for consumers, inefficient allocation of resources, and loss of national competitiveness. The Webbs' institutional theory of labor markets leads to considerably different predictions and interpretations. In particular (S. Webb 1912), these national minima: (1) ensure wages, hours and conditions are not below socially acceptable levels, (2) end employers' industrial parasitism and profit bounties, (3) offset employers' monopoly/monopsony power and other structural causes of labor's unequal bargaining power, (4) promote static allocative efficiency by equalizing private and social labor cost, (5) promote static efficiency by positive motivation of labor though higher and fairer wages, (6) promote dynamic efficiency by shifting profit-seeking from the low road of labor commodification to the high road of human capital investment, (7) promote dynamic efficiency by spurring firms to shift from a labor cost reduction strategy to one focused on improved management, better technology, and higher quality products, (8) stabilize the wage/price structure from collapse during recessions and depression, (9) redistribute economic rents going 
primarily to property owners, rentiers, and the affluent to either the government for social investment or to the middle and lower income groups in higher wages and better work conditions, and (10) reduce industrial conflict and adversarialism. From the Webbs' perspective, all of these beneficial effects of a National Minima arise because labor markets are fundamentally different than commodity markets, per their observation that "In the arithmetic of labor.... two from ten might leave, not eight or nine, but even eleven" (1902: 127).

The Webbs devote the last one-third of Industrial Democracy to four chapters on "Trade Union Theory." It is impossible to review this theory here (see Flanders 1968; Dickman 1987; Kaufman 2005, 2012c; Farnham 2008). It must suffice to note that the Webbs take a surprisingly ambivalent stance on trade unions. In the short run, trade unions are necessary and desirable because they help equalize bargaining power, raise wages and conditions to (at least) a social cost level, take wages out of competition through common rules across markets, and press the government for worker-friendly legislation. The Webbs also catalog a variety of negative effects of trade unions. For example, their coverage and bargaining power are greatest for the skilled workers who need them least and correspondingly least for workers in the sweated trades; likewise, unions raise wages to monopolistic levels, engage in organizing and bargaining sectionalism, foster adversarialism with employers, and employ a variety of restrictive practices.

In the long run, the Webbs argue ongoing legal enactment and socialization of industry necessitates that trade unions shift from autonomous bargaining agents to social co-partners in the management of industry (1897: 803-04). In the short run, they advocate greater use of industry and national courts of arbitration and conciliation, as pioneered in Australia and New Zealand, to harmonize trade union self-interest with the commonweal.

Conclusion 
The Webbs founded the LSE in 1895 to serve as a platform for development and teaching of a new paradigm in economics. It combines ideas from classical, neoclassical and Marxian theories; makes historical, institutional, and social structure a key explanatory component; portrays economies as incapable of self-regulation and prone to unbalance, injustice and waste; and charts a middle-way program of gradual social reform between the Scylla of Marxian revolution and Charybdis of neoclassical laissez-faire and status quo. The Webbs give particular emphasis to the efficiency and equity gains to be had from regulating and balancing labor markets, democratizing firm governance systems, and giving workers effective voice in the polity through extension of suffrage rights, trade union political representation, and formation of a labor party.

Up to World War II the Webbs were among the most influential labor writers in the world; today, however, the only acknowledgement they get is occasional citation to the trade union part of their work. Thus, contemporary labor scholars either have forgotten or never realized that the Webbs in Industrial Democracy and other works took on a much larger project than union studies. That is, like Commons and colleagues in the USA, they realized that their advocacy of labor market regulation and stabilization through devices such as trade unions, minimum wage laws, and internal arbitration systems would always struggle to gain scientific and public credibility unless and until it is anchored on a solid theory of labor markets and political economy. Since the alternative vision they developed has largely become lost in the mists of time, I have devoted this article to describing it anew. This review is partly a useful exercise in the history of thought. Much more important, however, is using it as a tool for building and strengthening an alternative institutional paradigm in labor economics and re-broadening industrial relations from its post-World War II "mostly union studies" orientation (ironically, often justified by citation to the Webbs' Industrial Democracy) back to its original early 20th century focus on the employment relationship, labor problems, and their institutional solution. 
References

Adams, Henry. 1886. "Relation of the State to Industrial Action." Publications of the American Economic Association 1(6): 7-85.

Akerloff, George, and Janet Yellen. 1990. "The Fair Wage-Effort Hypothesis and Unemployment." Quarterly Journal of Economics 105(2): 255-84.

Allen, Mathew, and Patrick Wright. 2007. "Strategic Management and HRM." In The Oxford Handbook of Human Resource Management, edited by Peter Boxall, John Purcell, and Patrick Wright, pp. 88-107. Oxford: Oxford University Press.

Bevir, Mark. 1989. "Fabianism and the Theory of Rent." History of Political Economy 10(2): 31327. 2002. "Sidney Webb: Utilitarianism, Positivism, and Social Democracy." Journal of Modern History 74 (June): 217-52.

Boulding, Kenneth. 1957. "A New Look at Institutionalism.” American Economic Review 47 (May): $1-12$.

Boyer, George, and Robert Smith. 2001. The Neoclassical Tradition in Labor Economics." Industrial \& Labor Relations Review 54(2): 199-23.

Clarkson, Jesse. 1953. "The Background of Fabian Theory." Journal of Economic History 13(4): 462-71.

Coase, Ronald. 1992. "The Institutional Structure of Production." American Economic Review 82 (3): 713-19. 
Cole, G.D.H. 1971. Fabian Socialism. London: Cass.

Commons, John. 1893. The Distribution of Wealth. New York: Kelly.

1924. The Legal Foundations of Capitalism. New York: Macmillan.

1934a. Myself. Madison: University of Wisconsin Press.

. 1934b. Institutional Economics: Its Place in Political Economy. New York: Macmillan.

Davanzati, Gugliemo, and Andrea Pacella. 2004. "Sidney and Beatrice Webb: Towards an Ethical Foundation of the Operation of the Labor Market." History of Economic Ideas 12:25-49.

Davis, John. 1992. The Economic Surplus in Advanced Economies. Northampton, MA: Elgar.

Dessing, Markye. 2002. "Labor Supply, the Family and Poverty: the S-Shaped Labor Supply Curve." Journal of Economic Behavior and Organization 49: 433-58.

Dickman, Howard. 1987. Industrial Democracy in America: Ideological Origins of National Labor Policy. LaSalle: Open Court.

Doeringer, Peter, and Michael Piore. 1971. Internal Labor Markets and Manpower Analysis. Lexington: Lexington Books.

Domhoff, William. 1990. The Power Elite and the State: How Policy is Made in America. New York: Aldine de Gruyer.

Douglas, Paul. 1921. "Shop Committees: Substitute for, or Complement to, Trade-Unions?” Journal of Political Economy 29(2): 89-107. . 1948. "Are There Laws of Production?" American Economic Review 38(1): 1-41. 
Durbin, Elizabeth. 1984. "Fabian Socialism and Economic Science." In Fabian Essays in Socialist Thought, edited by Ben Pimlott, pp. 39-53. London: Heinemann.

Eriguchi, Taku. "The Webbs, Public Administration and the LSE: The Origin of Public Governance and Institutional Economics in Britain." History of Economics Review 50 (Summer): 17-30.

Farnham, David. (2008). "Beatrice and Sidney Webb and the Intellectual Origins of British Industrial Relations." Employee Relations, 30: 534-52.

Fehr, Ernst, Lorenz Goette, and Christian Zehnder. 2009. “A Behavioral Account of the Labor Market: The Role of Fairness." Annual Review of Economics, 1: 355-84.

Flanders, Allan. 1968, "Collective Bargaining: A Theoretical Analysis." British Journal of Industrial Relations 6(1): 1-26.

Fox, Alan. 1974. Beyond Contract: Work, Power, and Trust Relations. London: Faber and Faber.

Freeman, Richard, and James Medoff. 1984. What Do Unions Do? New York: Basic Books.

Frege, Carola. 2008. "The History of Industrial Relations as a Field of Study." In Sage Handbook of Industrial Relations, edited by Paul Blyton, Nicolas Bacon, Jack Fiorito, and Edmund Heery, pp. 35-52. London: Sage.

Fried, Barbara. 1998. The Progressive Assault on Laissez Faire: Robert Hale and the First Law and Economics Movement. Cambridge, MA: Harvard University Press.

Friedman, Milton. 1953. Essay in Positive Economics. Chicago: University of Chicago Press.

Gordon, David, Richard Edwards, and Michael Reich. Segmented Work, Segmented Workers. Cambridge: Cambridge University Press. 
Harrison, Royden. 2000. The Life and Times of Sidney and Beatrice Webb, 1858-1905: The

Formative Years. London: Palgrave.

Heckscher, Charles, and Paul Adler. 2006. The Firm as a Collaborative Community:

Reconstructing Trust in the Knowledge Economy. Oxford: Oxford University Press.

Hobson, John. 1891. "The Law of the Three Rents." Quarterly Journal of Economics 5(3): 263-88.

1900. The Economics of Distribution. New York: Kelly.

Hyman, Richard. 1989. The Political Economy of Industrial Relations. London: MacMillan.

Irvine, William. 1947. "Shaw, the Fabians, and the Utilitarians." Journal of the History of Ideas 8

(2): 218-31.

Jacoby, Sanford. 1990. "The New Institutionalism: What Can It Learn from the Old?" Industrial Relations 29(2): 316-40.

Kadish, Alon. 1993. "The City, the Fabians and the Foundation of the London School of Economics." In The Market for Political Economy, edited by A. Kadish and K. Tribe, pp. 227-50. London: Routledge.

Kaufman, Bruce. 1998. "The Regulation of the Employment Relationship: The Perspective of the Original Institutionalists," Journal of Economic Behavior and Organization 34(3): 349-85. . 2004. The Global Evolution of Industrial Relations. Geneva: ILO. . 2005. "Historical Insights: the Early Institutionalists on Trade Unionism and Labor Policy." Journal of Labor Research 26(1): 1-32. 
2006. "Industrial Relations and Labor Institutionalism: A Century of Boom and Bust,"

Labor History 47(3): 295-318.

. 2009. "Promoting Labor Market Efficiency and Fairness through a Legal Minimum Wage:

The Webbs and the Social Cost of Labor." British Journal of Industrial Relations 47(2):

327-38.

. 2010. "The Theoretical Foundation of Industrial Relations and Its Implications for Labor Economics and Human Resource Management." Industrial and Labor Relations Review 64(1): 74-108.

. 2012a. "The History of the British Industrial Relations Field Reconsidered: Getting from the Webbs to the New Employment Relations Paradigm." British Journal of Industrial Relations 50(7): 1-32.

. 2012b. "Wage Theory, New Labor Policy, and the Great Depression: Were Government and Unions to Blame?" Industrial and Labor Relations Review 65(4): 1-32.

2012c. "An Institutional Economic Analysis of Labor Unions." Industrial Relations 51(S1);

438-71.

Kelly, John. 1998. Rethinking Industrial Relations: Mobilization, Collective Action, and Long Waves. London: Routledge.

Kerr, Clark. 1977. Labor Markets and Wage Determination. Berkeley, CA: University of California Press.

Keynes, John. 1936. The General Theory of Employment, Interest, and Money. London: Harcourt. 
Koot, Gerard. 1987. English Historical Economics, 1870-1926. Cambridge, MA: Cambridge University Press.

Lobdell, Richard. 1995. "The Theory of Rent in Fabian Economics." In The Peasant in Economic Thought: 'A Perfect Republic', edited by E. Forget and R. Lobdell, pp. 71-80. Brookfield, VT: Elgar.

Marshall, Alfred. 1890. Principles of Economics, 1st ed. (8th ed. 1920). New York: Macmillan.

Marx, Karl. 1867/1936. Capital: A Critique of Political Economy, Vol. 1 (Vols. 2 \& 3 1885). New York: Modern Library.

McNulty, Paul. 1980. The Origin and Development of Labor Economics. Cambridge, MA: MIT Press.

Millis, Harry, and Royal Montgomery. 1945. Organized Labor. New York, NY: McGraw Hill.

Neilson, William. 2007. Personnel Economics. Upper Saddle River, NJ: Prentice-Hall.

Nolan, Barbara. 1988. The Political Theory of Beatrice Webb. New York, NY: AMS Press.

Perlman, Mark, and Charles McCann. 1998. The Pillars of economic Understanding: Ideas and Traditions. Ann Arbor, MI: University of Michigan Press.

Phelps-Brown, Henry. 1977. The Inequality of Pay. Berkeley, CA: University of California Press.

Rader, Benjamin. 1966. The Academic Mind and Reform: The Influence of Richard T. Ely in American Life. Lexington, KY: University of Kentucky Press.

Reisman, David. 1976. Adam Smith's Sociological Economics. London: Croom Helm. 
Ricci, David. 1969. "Fabian Socialism: A Theory of Rent as Exploitation." Journal of British Studies $9(1): 105-21$.

Ricardo, David. 1817/1937. Principles of Political Economy and Taxation. London: Dent.

Rueschemeyer, Dietrich, and Ronan Van Rossem. 1996. "The Verein für Sozialpolitik and the Fabian Society." In States, Social Knowledge, and the Origins of Modern Social Policies, edited by Dietrich Rueschemeyer and Theda Skocpol, pp. 117-62. New York: Sage.

Rutherford, Malcolm. 2007. "American Institutionalism and its British Connections.” European Journal of the History of Economic Thought 14(2): 291-23.

2011. The Institutionalist Movement in American Economics, 1918-1947. Cambridge: Cambridge University Press.

Samuels, Warren, and A. Allan Schmid. 1981. Law and Economics: An Institutional Perspective. Boston, MA: Kluwer-Nijhoff.

Schumpeter, Joseph. 1954. History of Economic Analysis. Oxford: Oxford University Press.

Smith, Adam. 1776/1937. An Inquiry into the Nature and Causes of the Wealth of Nations. New York, NY: Random House.

Sørenson, Aage. 1996. "The Structural Basis of Inequality." American Journal of Sociology 101(5): 1333-65.

Stabile, Donald. 2008. The Living Wage: Lessons from the History of Economic Thought. Armonk, NY: M.E. Sharpe Stigler, George. 1959. "Bernard Shaw, Sidney Webb, and the Theory of Fabian Socialism," Proceedings of the American Philosophical Society 103(3): 469-75. 
Thompson, Noel. 1996. Political Economy and the Labor Party. London: UCL Press.

Webb, Beatrice. 1926. My Apprenticeship. London: Longmans, Green.

Webb, Sidney. 1912. "The Economic Theory of the Legal Minimum Wage." Journal of Political Economy 20: 973-98. , and Beatrice Webb. 1894. History of Trade Unionism. London: Amalgamated Society of Engineers, and 1897. Industrial Democracy. London: Longmans, Green and 1902. Problems of Modern Industry. New York: New World. and 1923. The Decay of Capitalist Civilization. Westminster: Fabian Society.

White, Roger. 2010. “Long-run Wage and Earnings Losses for Displaced Workers." Applied Economics 42: 1845-56.

Wolman, Leo. 1961. Reminiscences of Leo Wolman. New York: Columbia University Oral History Research Office. 